\title{
Economic Growth, Economic Development, and Poverty: A Bibliometric Analysis
}

\author{
Amra Babajić \\ University of Tuzla \\ Bosnia and Herzegovina \\ amra.babajic@untz.ba

\section{Mirza Suljić} \\ University of Tuzla \\ Bosnia and Herzegovina \\ mirza.suljic@untz.ba

\section{Sanel Halilbegović} \\ International Burch University \\ Bosnia and Herzegovina \\ sanel.halilbegovic@ibu.edu.ba
}

\begin{abstract}
The pertinacious problem of poverty in the world questions whether the existing mechanisms are effective in the poverty reduction process. Exploring this field has intensified since 1989, and this research provides an overview of the theoretical and empirical research that addresses economic development and poverty. Bibliometric analysis is performed, which includes names of the most common authors, journals, and countries of publications, as well as the frequency of words and expressions in the existing literature. Bibliometric units are researched from the Scopus database using keywords "economic development", "economic growth" and "poverty". The main contribution of this analysis is the review of existing literature addressing the key issues and identifying theoretical and empirical research in the field of economic development and poverty. This is the first study of its kind where scientific attention is being paid to economic growth, economic development, and poverty by the most influential journals and most prominent authors in economics.
\end{abstract}

Keywords: the economic theory, economic policy, poverty, keyword analysis

JEL classification: O10, I30, B26 


\section{Introduction}

If we adopt the fact, that economic development must be directed towards improving the lives we live and freedoms we enjoy, and that hunger is not just a consequence of nature but also an economic and political disaster, we can conclude that all poverty-related factors interact with economic development as well. In strictly economic terms, "development has traditionally meant achieving sustained rates of growth of income per capita, to enable a nation to expand its output at a rate faster than the growth rate of its population. Levels and rates of growth of "real" per capita gross national income (GNI) (monetary growth of GNI per capita minus the rate of inflation) are then used to measure the overall economic well-being of a population-how much of real goods and services are available to an average citizen for consumption and investment" (Todaro \& Smith, 2015, p.16). More recent views of economic thought emphasize that economic development includes structural and institutional changes and produces quantitative and qualitative changes in society, primarily focused on the reduction of poverty and inequality. Besides, „environmental constraints dictate a different type of economic development today, a development that brings about new economic structures and lifestyles that do less damage to the natural systems that sustain life on Earth"(Van den Berg, 2017, p. 8).

On the other side, economic growth refers to an increase of quantitative indicators of an economy, increase in output per capita in a certain period. During the 1950s and 1960s, economic development was observed as a series of successive stages of economic growth, and "development became synonymous with rapid, aggregate economic growth" (Todaro \& Smith, 2015, p.119). The subsequent development theories observed those phenomena separately, however, the authors decided to include both of these closely related phenomena in the analysis. Definitions and measures of poverty measured vary across the world. "The national poverty line for a country is typically a monetary threshold below which a person's minimum basic needs cannot be met, taking into account the country's economic and social circumstances" (World Bank, 2020a). According to a definition of relative poverty, "a person or a household is considered to be poor when their income and resources are worse than what is thought to be adequate or socially acceptable in the society in which they live" (Council of Europe, 2020). Therefore, someone can be poor in a relative meaning, even if they are not poor in the absolute sense. Developing countries usually use absolute lines but "most developed countries use relative poverty lines" (Ravallion \& Chen, 2011, p. 1251). In Europe, poverty is a synonym with relative poverty. Except for low income per capita, measured by the purchasing power parity, a poor world is characterized by inadequate nutrition, poor health (high prevalence of infectious diseases), high mortality rates - especially in young people, poor living conditions, low educational attainment, poor or absence of involvement in political and social programs, frequent social unrest and wars, existence in ecologically polluted areas, and so on. When "10 percent of the world's population (736 million people) lived on less than US $\$ 1.90$ a day in 2015" (World Bank, 2020b), exploring these topics is more than necessary.

To achieve the research aim, we defined the following research questions: Who are the most prominent authors in the field of economic growth, development, and poverty? What are the most frequently cited articles? What are the leading scientific journals? Which countries and authorships contribute the most to economic growth, development, and poverty? What are the most used keywords in this area?

The results of this study provide useful information in the field of research economic development and poverty. The research is structured as follows: the second part gives theoretical background and presentation of previous research. Part three outlines' data and methodology, while the fourth part provides analysis and discussion of the empirical results and in the end conclusions and research opportunities.

\section{Theoretical background and literature review}

Poverty issues are now in the focus of development economics, and they are one of the most controversial topics of economic analysts and historians. Economic development directions evolved and a lot of theories, strategies, and politics, which seek to reduce poverty in the world, have been developed. It has been commonly held that economic growth does not necessarily lead to poverty or income inequality reduction, 
and that support programs and financial and social assistance to the poor are the keys. Approaches to the link between economic growth and poverty changed over time. From the 1950s to early 1970s, theories like Kuznets inverted U, Rostow's stages of economic growth, Nurkse's vicious circle of poverty, were prevalent in the field of economic growth and development. However, the increase in poverty and inequality, during the 1980s and 1990s, led to a conclusion that it is not possible to consider growth separate from poverty. New theories since the 1990s emphasize the inextricable link between economic growth, economic development, and poverty: (Adams, 2003; Fields, 1989; Kwon \& Yi, 2015; Lopez, 2006; Ravallion \& Chen, 1999; Roemer \& Gugerty, 1997; Škare \& Družeta, 2016), and so on.

The nexus between economic growth and poverty varies among different authors, countries, and periods. According to DFID "economic growth is the most powerful instrument for poverty reduction and improving quality of life in developing countries. Strong growth and employment opportunities encourage parents to invest in the education of their children" (DFID, G. B., 2008, p. 2). It can lead to the emergence of strong and growing groups of entrepreneurs who would then increase pressure on governments for better management. Islam (2004) conceptualized a virtuous circle of links between growth, employment, and poverty reduction from which economic growth leads to productive capacity, productive capacity then leads to employment with rising productivity, which leads to higher income of poor, where the higher income of poor leads to higher expenditure on health, education and skills development, which in the end, increases productive capacity (Islam, 2004). Economic growth and development result in creating new jobs, driving human development, and improving health and education, which ultimately have effects on the quality of life of all people in society. Creating new jobs gives society better employment opportunities, which directly correlates with poverty reduction because people become a part of the working population that can afford at least a minimum of goods and thus rise above poverty. Increasing wages contributes to poverty reduction too, as it increases the solvency of the population and the ability to provide better living conditions for the same level of work.

Some recent bibliometric analyses focus on the top economic journals, main topics, top publishing, and most cited authors and institutions. Lahat (2017) emphasizes that scientific findings of poverty are one of the main factors that influence policymakers' perceptions on how to deal with this problem. Knowledge of the phenomenon of poverty is very important, often more notable for observation than exposure to it. (Lahat, 2017).

Teixeira and Carvalho (2014) used bibliometric analysis and managed to measure the number of attention authors paid to poverty and poor countries. They identified and analyzed papers published in the most prominent journals in the area of international economics between 1971 and 2010. They concluded that 'Poverty authors pay little attention to this matter, "representing only $0.6 \%$ of all articles, which corresponds to the absolute value of 13 in a total of 1,740 articles" (Teixeira \& Carvalho, 2014, p. 22).

Cardoso and Teixeira (2020) conducted the bibliometric analysis with a focus on poverty in the most influential journals in economics and highlighted two main findings:

(i) the scientific attention paid to poverty in the Blue-Ribbon journals (top American economic journals) is relatively deficient, but with a positive trend, "increasing from a modest 0.36 percent of total articles published in the 1970s to 1.92 percent of total publications in 2010s"; and

(ii) "relative weight of specific poverty subtopics has significantly changed over the last 50 years, shifting from a focus on defining and measuring poverty, to policy-related issues in the most recent period (2000 onward)" (Cardoso \& Teixeira, 2020, p. 1).

Ravallion (2011) used Google Books Ngram Viewer to analyze the evolution of attention to poverty and related topics in the literature. He documented the number of times the word 'poverty' appears in books and one of the conclusions is that there have been "significant changes in attitudes about poverty over the last three centuries and even contempt for poor people, to the view that society, the economy, and government should be judged in part, at least by their success in reducing poverty" (Ravallion, 2011, p. 43). This research provides a content analysis of poverty-related keywords and poverty subtopics addressed in the relevant literature. There are not many papers dealing with bibliometric analysis in the field of economic development and poverty and this research is the first or one of the first ones in this area. 


\section{Methodology}

Bibliometric analysis

The bibliometric analysis employs quantitative methods to investigate the scientific activity within a specific field and is entirely dependent on available written publications that have been preserved and stored in a bibliographic database. Bibliometric techniques have evolved, and two of them stand out: performance analysis and science mapping. Performance analysis focuses on measuring publication, impact (often used as a proxy for quality) for authors, journals, institutions, countries, and keywords, while science mapping is intended to explore into dynamics of a research field over a particular period.

\section{Choice of database}

This research used the SCOPUS databases to retrieve publications from 1970 to 2019. Since all the main journals and conferences, covering economic issues, are included in the SCOPUS database, and bibliometric analysis was conducted using studies published in Scopus up until May 2020. Scopus was chosen because it includes more than 22000 titles, from more than 5000 international publishers, containing different types of documents, along with other relevant metadata that is relevant and important to this research (Aghaei Chadegani, A. et al., 2013).

We searched for publications related to economic development and poverty of all types, by their titles, abstracts, and keywords. The search query string was designed to cover as many results as possible that met our requirements as described below. Keywords included in the search were 'Poverty' AND ('Economic development' OR 'Economic growth') utilizing the Boolean operator 'or' in the title, abstract, and keyword field. Moreover, since our focus was on economics, we chose, as an additional filter, AND/NOT (disease OR health OR cancer OR infections OR Terrorism OR flood OR Agriculture OR mortality OR violence OR biodiversity OR Ecosystem OR Forest OR Urbanism OR nutrition). We limited literature to the subject areas of "Social Sciences", "Economics, Economics, and Finance" and "Business, Management, and Accounting." The survey was conducted during the last week of May of 2020, and a total of 4415 publications were returned from the main search. The validity of the search strategy was tested by manually reviewing the retrieved articles.

Table 1: The query and additional search options are used during the search

\begin{tabular}{|l|l|}
\hline \multicolumn{1}{|c|}{ Search query } & \multicolumn{1}{|c|}{ Additional search options } \\
\hline $\begin{array}{l}\text { (Poverty) AND ("Economic development" OR "Economic } \\
\text { growth") }\end{array}$ & Advanced search: \\
AND NOT (disease OR health OR cancer OR & Date: 27. August 2020 \\
infections OR Terrorism OR flood OR Agriculture OR & Use field: TITLE-ABS-KEY \\
mortality OR violence OR biodiversity OR Ecosystem & \\
OR Forest OR Urbanism OR nutrition) & \\
AND EXCLUDE (PUBYEAR, 2020) & \\
AND (LIMIT-TO (SUBJAREA, "SOCI") & \\
OR LIMIT-TO (SUBJAREA, "ECON") & \\
OR LIMIT-TO (SUBJAREA, "BUSI")) & \\
Refined by: Databases: ( Scopus ) & \\
Timespan= 1970 -2019 & \\
Search language=Auto & \\
\hline
\end{tabular}

Source: Authors' work 


\section{Results and discussion}

Our research shows that topics related to poverty and economic growth and development have drawn significant attention from scientists in the last few decades. Another research similarly presented and concluded that understanding the importance top economics journals give to poverty is relevant mainly because of the impact these scientific sources have on policymakers (Cardoso and Teixeira, 2020, p. 13).

\section{Results of the activity indicators}

Based on the search criteria previously defined in Table 1, Figure 1 shows the number of publications published over time, in terms of compatibility with the time frame of those collected publications. Besides an overall number of published publications, numerous publications can be also seen in the following domains: "Social Sciences", "Economics, Econometrics and Finance" and "Business, Management, and Accounting." It is essential to mention that the publication may be included in several categories (subject areas) according to SCOPUS rules.

Figure 1. Number of publications relevant to Economic Growth, Economic Development, and Poverty by year of publication

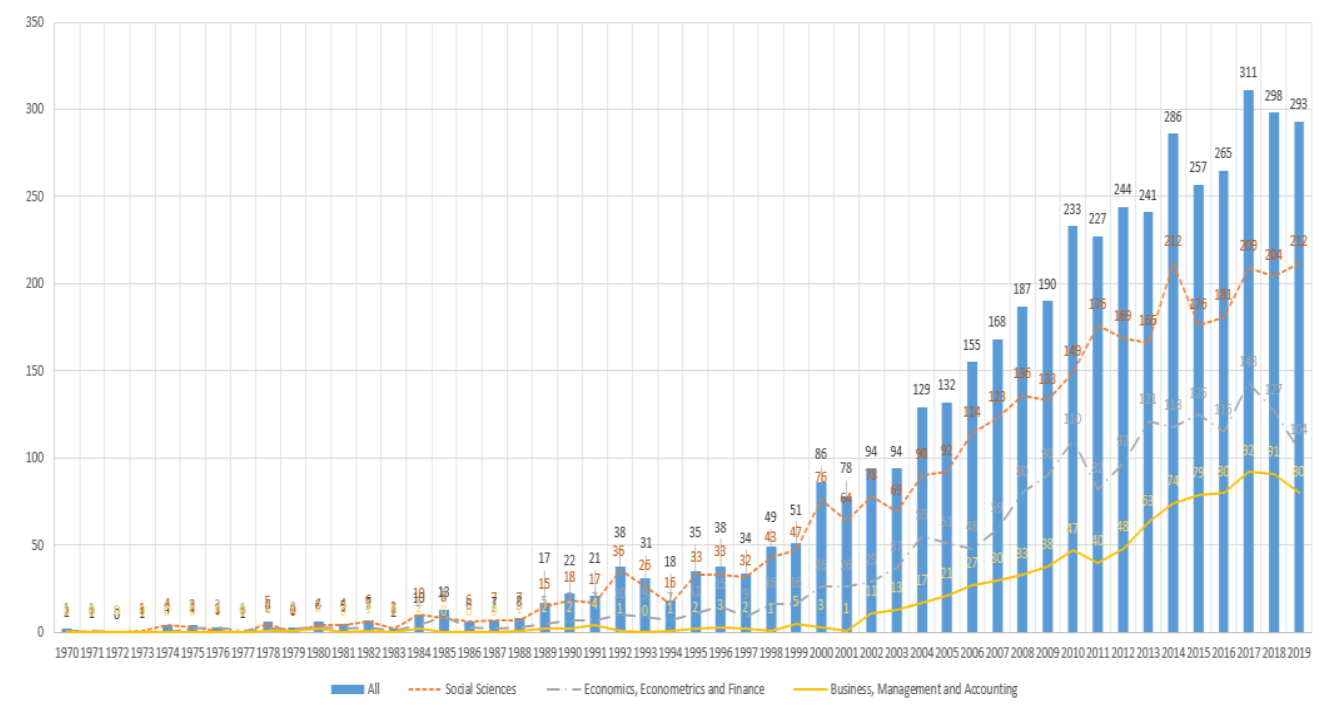

Source: Authors' research from the SCOPUS database

Regarding the number of publications per year, Figure 1 depicts the growing pattern of Poverty and Economic Growth and Development in the last forty years. To present the importance of the subject for literature, Appendix 1 shows the total number of publications and related topics published in Scopus in the subject areas 'Social Sciences', 'Economics, Econometrics and Finance' and 'Business, Management, and Accounting'. Data shows that the total number of publications in the area of "Social Sciences" increased from 15,109 in 1970 to 338,553 in 2019, while the number of topic publications increased from 1 to 212 in the observed period. When it comes to the subject area "Business, Management, and Accounting" the total number of publications increased from 2,359 in 1970 to 106,419 in 2019, while the number of topic publications increased from 0 to 80 . In the subject area "Economics, Econometrics, and Finance", the total number of publications increased from 1,869 in 1970 to 60,999 in 2019, while the number of topic publications increased from 1 to 104 . The absolute number of publications published during the observation period is shown in Figure 2.

Figure 2. Publications related to Poverty and Economic Growth and Development by year of publication, relative terms (topic related publication vs total number of publications) 


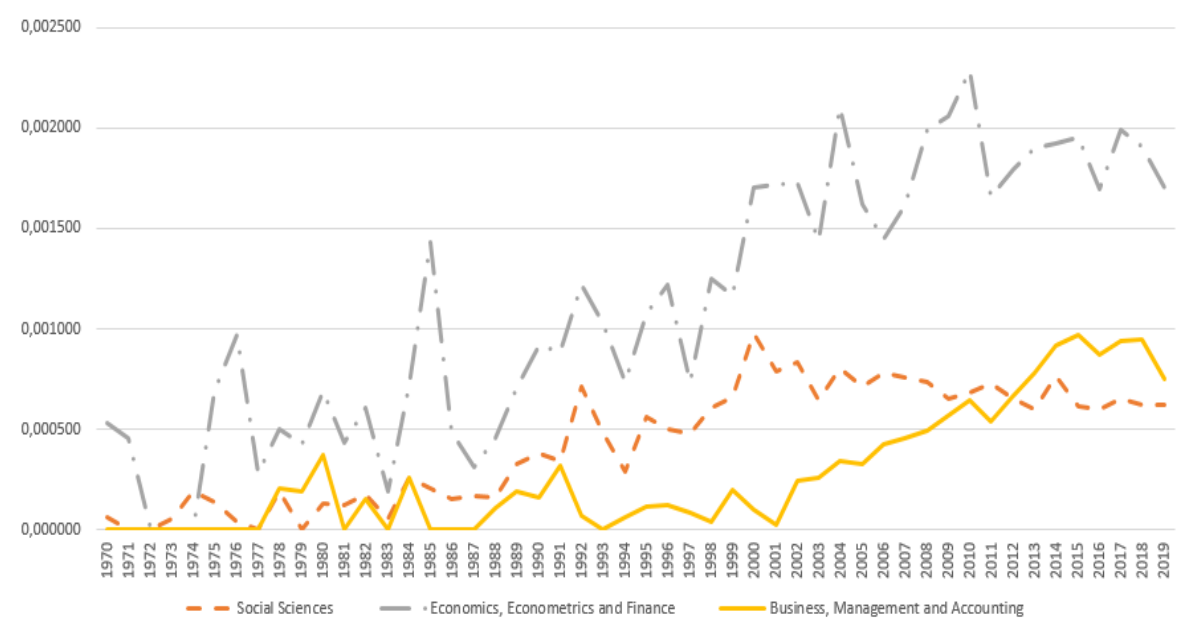

Source: Authors' research from the SCOPUS database

Although, in an absolute sense, the largest increase occurred in the field of Social Sciences, while in relative terms (topic-related publications vs a total number of publications) the largest increase occurred in the field of "Economics, Econometrics, and Finance", where the notable increase occurred in the period from 983 to1986. However, the largest increase in this field occurred from 2003 to 2011, whereupon the number of topic-related publications vs the total number of publications began to decline.

Since 1989, the highest number of publications per year is concentrated, which can be attributed to the World Bank, which has had a critical role in research on important issues. "Research on income distribution that has emerged over the years has sought to increase the understanding of donors, policymakers, and academics on the important questions of who benefits from economic development, who is hurt by economic decline, and why" (Fields, G. S., 1989, p. 2). Another reason for this is the progressive economic development in markets other than the US, especially in those of Europe and China. Table 2 shows the top authors based on the number of publications and citations per article.

Table 2. Most prominent authors who have published over 10 publications on Poverty and Economic Growth and Development (Accessed 03/02/2020, Revised 27/08/2020)

\begin{tabular}{|l|l|c|c|r|}
\hline \multicolumn{1}{|c|}{ Authors } & \multicolumn{1}{c|}{ Affiliation } & $\begin{array}{c}\text { Number of } \\
\text { publications }\end{array}$ & $\begin{array}{c}\text { Number of } \\
\text { Citations }\end{array}$ & $\begin{array}{c}\text { Citations } \\
\text { per article }\end{array}$ \\
\hline Martin Ravallion & Georgetown University & 21 & 1946 & 92.67 \\
\hline Nanak C. Kakwani & $\begin{array}{l}\text { University of New South } \\
\text { Wales UNSW Australia }\end{array}$ & 13 & 539 & 41.46 \\
\hline Ernesto M. Pernia & $\begin{array}{l}\text { University of the } \\
\text { Philippines Diliman }\end{array}$ & 13 & 384 & 29.54 \\
\hline Arsenio M. Balisacan & $\begin{array}{l}\text { University of the } \\
\text { Philippines Diliman }\end{array}$ & 12 & 182 & 15.17 \\
\hline Andy Sumner & King's College London & 12 & 103 & 8.58 \\
\hline Gary S. Fields & IZA & 10 & 155 & 15.50 \\
\hline
\end{tabular}

Source: Authors' research from the SCOPUS database

Martin Ravallion is the most prolific author with 21 publications, followed by Nanak C. Kakwani and Ernesto M. Pernia with 12 and Arsenio M. Balisacan and Andy Sumner with 12 publications. Looking at the number of citations per publication, the first three authors are Martin Ravallion with 92.67, followed by Nanak Kakwani with 41.46, and Ernesto M. Pernia with 29.57. Martin Ravallion is the most prominent author, however, his article titled "Growth, inequality, and poverty: Looking beyond averages" (2001) is one of the ten most frequently cited articles. Table 3 includes the 10 most cited publications based on the SCOPUS database. 
The most cited article (Table 3) is "A new data set measuring income inequality" (1996) by K. Deininger and L. Squire, published in the World Bank Economic Review with 1279 citations. This paper on the new data set explores the systematic nexus between growth and changes in aggregate inequality. They used the Gini coefficient for measuring changes in inequality and concluded that "there is a strong positive relationship between growth and poverty reduction and no systematic relationship between the growth of aggregate income and changes in inequality as measured". (Deininger \& Squire, 1996, p. 565).

Table 3. Ten of the most frequently cited articles according to the SCOPUS database, from the analyzed set of publications (Accessed 3/2/2020, Revised 27/08/2020)

\begin{tabular}{|c|c|c|c|c|}
\hline Citations & Author & Title & Year & Journal \\
\hline 1291 & $\begin{array}{l}\text { (Deininger, K. } \\
\& \text { Squire, L., } \\
\text { 1996) }\end{array}$ & $\begin{array}{l}\text { A new data set } \\
\text { measuring income } \\
\text { inequality }\end{array}$ & 1996 & $\begin{array}{l}\text { World Bank } \\
\text { Economic } \\
\text { Review }\end{array}$ \\
\hline 1277 & $\begin{array}{l}\text { (Glaeser, E. L., } \\
\text { La Porta, R., } \\
\text { Lopez-de- } \\
\text { Silanes, F., \& } \\
\begin{array}{l}\text { Shleifer, A., } \\
\text { 2004) }\end{array}\end{array}$ & $\begin{array}{l}\text { Do institutions cause } \\
\text { growth? }\end{array}$ & 2004 & $\begin{array}{l}\text { Journal of } \\
\text { Economic } \\
\text { Growth }\end{array}$ \\
\hline 990 & $\begin{array}{l}\text { (Dollar, D. \& } \\
\text { Kraay, A., } \\
\text { 2002) }\end{array}$ & $\begin{array}{l}\text { Growth is good for } \\
\text { the poor }\end{array}$ & 2002 & $\begin{array}{l}\text { Journal of } \\
\text { Economic } \\
\text { Growth }\end{array}$ \\
\hline 765 & $\begin{array}{l}\text { (Diener, E. \& } \\
\text { Biswas- } \\
\text { Diener, R., } \\
\text { 2002) }\end{array}$ & $\begin{array}{l}\text { Will money increase } \\
\text { subjective well- } \\
\text { being? A literature } \\
\text { review and guide to } \\
\text { needed research }\end{array}$ & 2002 & $\begin{array}{l}\text { Social } \\
\text { Indicators } \\
\text { Research }\end{array}$ \\
\hline 535 & $\begin{array}{l}\text { (Dollar, D. \& } \\
\text { Kraay, } \\
\text { 2004) }\end{array}$ & $\begin{array}{l}\text { Trade, growth, and } \\
\text { poverty }\end{array}$ & 2004 & $\begin{array}{l}\text { The Economic } \\
\text { Journal }\end{array}$ \\
\hline 508 & $\begin{array}{l}\text { (Rodrik, D., } \\
\text { 2008) }\end{array}$ & $\begin{array}{l}\text { One economics, } \\
\text { many recipes: } \\
\text { globalization, } \\
\text { institutions, and } \\
\begin{array}{l}\text { economic growth } \\
\text { (Book) }\end{array}\end{array}$ & 2008 & $\begin{array}{l}\text { Princeton } \\
\text { University } \\
\text { Press }\end{array}$ \\
\hline 496 & $\begin{array}{lr}\text { Beck, } & \text { T., } \\
\text { Demirgüç- } & \\
\text { Kunt, A., \& } \\
\text { Levine, } \\
\text { 2007) }\end{array}$ & $\begin{array}{l}\text { Finance, inequality, } \\
\text { and the poor }\end{array}$ & 2007 & $\begin{array}{l}\text { Journal of } \\
\text { Economic } \\
\text { Growth }\end{array}$ \\
\hline 471 & $\begin{array}{l}\text { (Beckerman, } \\
\text { W., 1992) }\end{array}$ & $\begin{array}{l}\text { Economic growth } \\
\text { and the environment: } \\
\text { Whose growth? } \\
\text { Whose environment? }\end{array}$ & 1992 & $\begin{array}{l}\text { World } \\
\text { Development }\end{array}$ \\
\hline 462 & $\begin{array}{l}\text { (Taylor, E. J., } \\
\text { 1999) }\end{array}$ & $\begin{array}{l}\text { The new economics } \\
\text { of labor migration } \\
\text { and the role of } \\
\text { remittances in the } \\
\text { migration process }\end{array}$ & 1999 & $\begin{array}{l}\text { International } \\
\text { Migration }\end{array}$ \\
\hline 436 & $\begin{array}{l}\text { (Ravallion, M., } \\
\text { 2001) }\end{array}$ & $\begin{array}{l}\text { Growth, inequality, } \\
\text { and poverty: Looking } \\
\text { beyond averages }\end{array}$ & 2001 & $\begin{array}{l}\text { World } \\
\text { Development }\end{array}$ \\
\hline
\end{tabular}


The second most cited article is "Do institutions cause growth?" (2004) by E.L. Glaeser, R. La Porta, F. Lopez-de-Silanes, while A. Shleifer was published in the Journal of Economic Growth with 1253 citations. This paper revisits the debate whether political institutions cause economic growth or, instead, whether the development and build-up of human capital accumulation lead to institutional improvement. They concluded that the evidence is non-existent, institutions cause economic growth, as opposed to growth improving institutions. Their analysis for the period from 1960 to 2000 provides no support for the claim that "institutions cause growth". Substantial evidence points to the primacy of human capital for both growth and democratization. Also, they showed that institutional results improve as the country becomes richer (Glaeser, et al., 2004).

The article "Growth is good for the poor" (2002) by D. Dollar, and A. Kraay was published in the Journal of Economic Growth with 960 citations. This paper underscores the importance of economic growth in reducing poverty and concludes that when average incomes rise, the average incomes of the poorest fifth of society rise proportionately. They emphasize that growth is not all that is necessary to advance the lives of the poor, and that good poverty reduction strategies must include tools of good rule of law, openness to international trade, good fiscal policy and discipline, and so on (Dollar \& Kraay, 2002).

"Will money increase subjective well-being? A literature review and guide to needed research" (2002) by Diener and Biswas-Diener were published in Social Indicators Research with 741 citations. They opened the question of whether the money will make people happy and concluded that a higher income might help if one is very poor. More money increases subjective well-being, "when it means avoiding poverty and living in a developed nation, however, income appears to increase subjective well-being little over the long-term, when more of it is gained by well-off individuals whose material desires rise with their incomes". The fundamental finding is "that for middle and upper-income people in developed countries, where gaining more income is not likely to enhance their subjective well-being" (Diener \& Biswas-Diener, 2002, p. 119).

The fifth most cited article is "Trade, growth, and poverty" (2004) by Dollar and Kraay, published in The Economic Journal. In this paper, the authors investigated how globalization and trade openness affect economic growth and poverty. They emphasize that economic growth leads to proportionate increases in incomes of the poor. "The evidence from individual cases and cross-country analysis supports the view that globalization leads to faster growth and poverty reduction in poor countries. Furthermore, there is no systematic relationship between changes in trade volumes and changes in household income inequality" (Dollar \& Kraay, 2002, p. 22).

Table 4. The seventeen most influential and productive journals according to Scopus (Accessed 3/2/2020, Revised 27/05/2020)

\begin{tabular}{|l|c|c|c|c|c|}
\hline Journals & $\begin{array}{c}\text { Citation } \\
\mathbf{s}\end{array}$ & $\begin{array}{c}\text { (\%) of } \\
\text { citation } \\
\mathbf{s}\end{array}$ & $\begin{array}{c}\text { Publicatio } \\
\text { ns }\end{array}$ & $\begin{array}{c}\text { (\%) of } \\
\text { publicatio } \\
\text { ns }\end{array}$ & $\begin{array}{c}\text { Average } \\
\text { citations } \\
\text { per } \\
\text { publicatio } \\
\text { n }\end{array}$ \\
\hline World Development & 4783 & $7.75 \%$ & 99 & $2.24 \%$ & 48.31 \\
\hline Social Indicators Research & 1035 & $1.68 \%$ & 20 & $0.45 \%$ & 51.75 \\
\hline Journal Of Development Studies & 936 & $1.52 \%$ & 25 & $0.57 \%$ & 37.44 \\
\hline $\begin{array}{l}\text { Journal Of International } \\
\text { Development }\end{array}$ & 861 & $1.40 \%$ & 56 & $1.27 \%$ & 15.38 \\
\hline Development Policy Review & 581 & $0.94 \%$ & 25 & $0.57 \%$ & 23.24 \\
\hline Asian Development Review & 498 & $0.81 \%$ & 23 & $0.52 \%$ & 21.65 \\
\hline Journal Of African Economies & 300 & $0.49 \%$ & 29 & $0.66 \%$ & 10.34 \\
\hline $\begin{array}{l}\text { Bulletin Of Indonesian Economic } \\
\text { Studies }\end{array}$ & 271 & $0.44 \%$ & 21 & $0.48 \%$ & 12.90 \\
\hline Economic Development Quarterly & 233 & $0.38 \%$ & 23 & $0.52 \%$ & 10.13 \\
\hline $\begin{array}{l}\text { International Journal Of Social } \\
\text { Economics }\end{array}$ & 228 & $0.37 \%$ & 35 & $0.79 \%$ & 6.51 \\
\hline
\end{tabular}




\begin{tabular}{|l|c|c|c|c|c|} 
Development Southern Africa & 214 & $0.35 \%$ & 23 & $0.52 \%$ & 9.30 \\
\hline Sustainability Switzerland & 203 & $0.33 \%$ & 30 & $0.68 \%$ & 6.77 \\
\hline Finance And Development & 199 & $0.32 \%$ & 20 & $0.45 \%$ & 9.95 \\
\hline African Development Review & 188 & $0.30 \%$ & 20 & $0.45 \%$ & 9.40 \\
\hline IDS Bulletin & 182 & $0.29 \%$ & 26 & $0.59 \%$ & 7.00 \\
\hline Pakistan Development Review & 142 & $0.23 \%$ & 36 & $0.82 \%$ & 3.94 \\
\hline $\begin{array}{l}\text { Mediterranean Journal Of Social } \\
\text { Sciences }\end{array}$ & 117 & $0.19 \%$ & 40 & $0.91 \%$ & 2.93 \\
\hline
\end{tabular}

Table 4. (continued)

The 17 most influential and productive journals, on topics including economic growth, economic development, and poverty, are identified and presented in Table 4. To measure the impact of each journal, the indicators are based on the number of citations of all published publications. Data presented in Table 4 identifies the most influential and productive journals on Economic Growth, Economic Development, and Poverty topic, based on the number of times all papers published by the journal are cited in other papers to measure the influence of each journal.

Data reveals that the World Development journal has the highest number of citations $(4783,7.75 \%)$ and articles $(99,2.24 \%$ ), followed by Social Indicator Research $(1035,1.68 \%)$, Journal of Development Studies (936, 1.52\%), Journal of International Development (861, 1.40\%), Development Policy Review (581, 0.94\%), Asian Development Review (498, 0.81\%), Journal of African Economies (300, 0.49\%), and so on. World Development is the multi-disciplinary international journal devoted to the Study and Promotion of World Development. When it comes to the average number of citations per publication, Social Indicators Research journal is in front of the World Development journal with an average of 51.75 citations per publication.

Figure 2 shows the citation network map of journals that classifies them into clusters based on citations among them. The weight of each node is represented by the size of nodes and words. The nodes of the same color belong to a cluster, while the distance between two nodes captures the strength of their relationship; shorter distance imports a stronger connection.

Figure 3. Citation journal map, generated with VOS Viewer

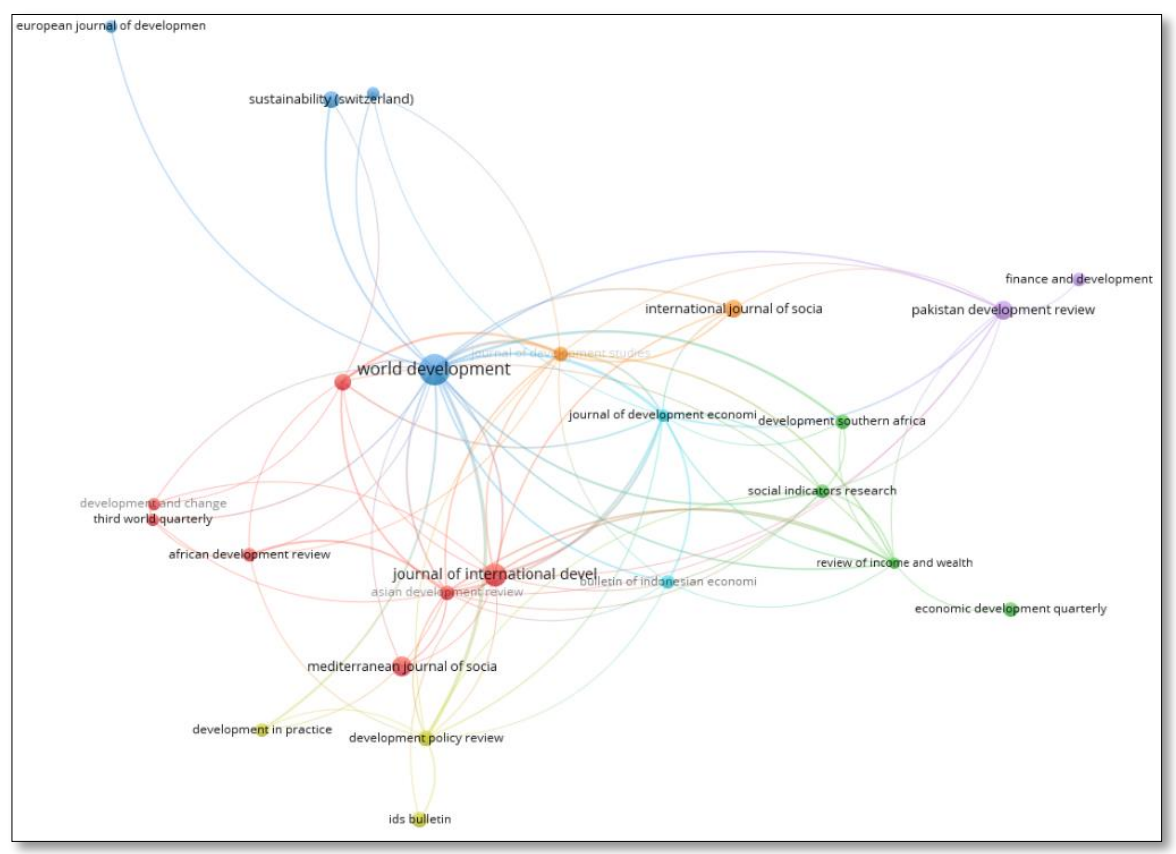


Consistent with the results shown in Figure 3, World Development and Journal of International Development journals have the highest node size. A total of seven clusters are identified by the VOS Viewer. The first one is formed by the World Development, European Journal of Development Research, Review of Development Economics and Sustainability (Switzerland). Cluster 2 includes African Development Review, Asian Development Review, Development, and Change, Journal of African Economies, Journal of International Development, Mediterranean Journal of Social Sciences, and Third World Quarterly. Cluster 3 is formed by the journal of Development Southern Africa, Economic Development Quarterly, Review of Income and Wealth and Social Indicators Research.

Cluster 4 includes Development in Practice, Development Policy Review, and IDS Bulletin. Cluster 5 includes Finance and development and Pakistan Development Review. Cluster 6 is formed by the Bulletin of Indonesian Economic Studies and Journal of Development Economics. Finally, Cluster 7 is composed of the International Journal of Social Economics and Journal of Development Studies.

Table 5 shows the 15 most influential countries based on the representation of defined countries/territories associated with the main search records identified in Scopus. With slightly less than one-fourth of the records found in this field, the United States of America dominates with 1131 publications. The United Kingdom, with approximately $11 \%$ of all identified publications, also has a major impact on this research area. India is a recent surprise. Thanks to the structural and political reforms and development of technological innovation, India's GDP growth has been among the highest in the world in the past decade, achieving an "annual growth of between 6-7\%" (Myers, J., 2020) which can be correlated to broader research in the field of economic development and poverty. No wonder the fact that the United States of America, the United Kingdom, and Australia are ranked first, due to their ranking according to the QS Higher Education System Strength Rankings 2018. The United States of America takes the first position in the world and is followed by the United Kingdom in second place. Australia takes the third position (QS Higher Education System Strength Rankings, 2020). India is a surprise and it is in the 26th position, while South Africa is in the 33rd position, and two of those countries are one of the first five countries among the most productive according to our bibliometric analyses. When it comes to government expenditure on education (\% of GDP), South Africa (2018) allocates $6.2 \%$ of its GDP on education, Australia (2016) $5.3 \%$, the United States of America (2014) 5.0\%, United Kingdom (2016) 5.5\%, India (2013) 3.8\%, and so on (World Bank, 2020).

Table 5. Fifteen of the most productive countries/territories according to Scopus (Accessed 3/2/2020, Revised 27/05/2020)

\begin{tabular}{|c|l|c|c|c|c|c|}
\hline & Country & $\begin{array}{c}\text { Number of } \\
\text { publications } \\
(\%)\end{array}$ & $\begin{array}{c}\text { Number of } \\
\text { citations for } \\
\text { publications }\end{array}$ & $\begin{array}{c}\text { Average } \\
\text { citation per } \\
\text { publications }\end{array}$ & $\begin{array}{c}\text { Year of a } \\
\text { first } \\
\text { published } \\
\text { article }\end{array}$ & $\begin{array}{c}\text { Year of Last } \\
\text { published } \\
\text { article }\end{array}$ \\
\hline 1 & $\begin{array}{l}\text { The United } \\
\text { States of } \\
\text { America }\end{array}$ & $1131(23.46)$ & 25367 & 22.43 & 1964 & 2019 \\
\hline 2 & United Kingdom & $534(11.08)$ & 9640 & 18.05 & 1985 & 2019 \\
\hline 3 & South Africa & $300(6.22)$ & 2326 & 7.75 & 1980 & 2019 \\
\hline 4 & India & $220(4.56)$ & 1110 & 5.05 & 1978 & 2019 \\
\hline 5 & Australia & $205(4.25)$ & 2168 & 10.58 & 1982 & 2019 \\
\hline 6 & China & $145(3.01)$ & 1255 & 8.66 & 1998 & 2019 \\
\hline 7 & Germany & $141(2.92)$ & 1000 & 7.09 & 1990 & 2019 \\
\hline 8 & Canada & $135(2.80)$ & 1889 & 13.99 & 1975 & 2019 \\
\hline 9 & Netherlands & $101(2.10)$ & 1146 & 11.35 & 1984 & 2019 \\
\hline 10 & France & $97(2.01)$ & 754 & 7.77 & 1970 & 2019 \\
\hline 11 & Malaysia & $78(1.62)$ & 579 & 7.42 & 1999 & 2019 \\
\hline
\end{tabular}




\begin{tabular}{|l|l|l|l|l|l|l|}
\hline 12 & Italy & $69(1.43)$ & 654 & 9.48 & 1978 & 2019 \\
\hline 13 & Japan & $67(1.39)$ & 516 & 7.70 & 1995 & 2019 \\
\hline 14 & Spain & $66(1.37)$ & 443 & 6.71 & 2000 & 2019 \\
\hline 15 & Indonesia & $65(1.35)$ & 284 & 4.37 & 1996 & 2019 \\
\hline
\end{tabular}

Table 5. (Cont'd)

The majority, six of these fifteen most productive countries/territories are in Europe, while five are in Asia, two are in North America and one is in Oceania and Africa, which means that this is a topic of interest in many regions around the world. The United States of America had the largest number of total citations with 25,367, followed by the United Kingdom with 9,640, and South Africa with 2,326. Considering the average citations per article, the United States of America is top-ranked again with 22.43, followed by the United Kingdom with 18.05, and Canada with 13.99. By contrast, Indonesia (4.37), India (5.05), and Spain (6.71) had the lowest number of citations relative to the number of published articles. Finally, Table 4 shows the first year and the last year these countries published at least one publication in the field of poverty and economic development. Countries such as the United States of America, France, and Canada have had publications since the beginning of the study period, while the other countries began publishing between 1978 and 2000. In 2019, all these countries continue to regularly publish work on this topic.

\section{Keywords analysis (co-occurrence)}

Keywords are a significant part of a publication and represent the core content; specific associations formed between keywords will identify the degree of the academic level of interest in the field through keyword analysis. In this research, the authors use keyword co-occurrence analysis to address highly popular topics in the field of poverty and economic development. A total of 4372 publications had 7997 keywords, most of which are not frequently used, with a small number of keywords that are often used. Surely, the most frequently used keyword is 'poverty' with the highest frequency of occurrence, followed by 'economic growth', 'economic development, 'poverty alleviation, 'economics', 'sustainable development, 'developing countries, and 'income distribution'. Twenty-five keywords with an appearance of more than 20 times are shown in Table 6.

Table 6. Most important keyword(s)

\begin{tabular}{|l|c|l|c|}
\hline \multicolumn{1}{|c|}{ Keyword } & $\mathrm{F}$ & \multicolumn{1}{|c|}{ Keyword } & $\mathrm{F}$ \\
\hline 1. Poverty & 1093 & 14. Development & 149 \\
\hline 2. Economic growth & 1082 & 15. Economics & 138 \\
\hline 3. Economic development & 865 & 16. Sub-Saharan Africa & 126 \\
\hline 4. Poverty alleviation & 652 & 17. Growth & 123 \\
\hline 5. Income distribution & 251 & 18. South Africa & 123 \\
\hline 6. Africa & 210 & 19. Employment & 122 \\
\hline 7. Inequality & 207 & 20. Globalization & 120 \\
\hline 8. Developing world & 193 & 21. Developing countries & 117 \\
\hline 9. Sustainable development & 190 & 22. Poverty reduction & 116 \\
\hline 10. Asia & 188 & 23. Social policy & 104 \\
\hline 11. India & 161 & 24. Developing country & 97 \\
\hline 12. China & 156 & 25. Economic policy & 90 \\
\hline
\end{tabular}




\section{Table 6. (Cont'd)}

\begin{tabular}{|l|l|l|l|}
\hline 13. Eurasia & 151 & & \\
\hline
\end{tabular}

It was expected that keywords such as 'poverty', 'economic growth, 'economic development, 'poverty alleviation, 'income distribution' are those that are first ranked. Africa and Sub-Saharan Africa are regions with the highest poverty rates in the world and they are very often mentioned and analyzed in papers and publications. Other keywords are closely related to the phenomenon of poverty and economic growth. China is one of the most productive countries, and it has generated about 3 percent of all publications on economic growth, economic development, and poverty. According to Table 6, the word "China" is one of the important keywords. This is not surprising, since China has recently been characterized as the new center of gravity of the global economy. Today, China is a global economic superpower, a locomotive of global economic growth, a country with the second economic power and the second place in world exports, a country with the largest foreign trade surplus and the largest foreign exchange reserves, and a country whose economic growth has been the highest in the world for decades.

Following the preliminary consolidation of keywords, the co-occurrence network was employed to identify and represent identifiable networks of high-frequency co-keywords in the field of poverty and economic development. Using natural language processing techniques, keywords from analyzed publications are used to determine the frequency of given words ('co-words') that appear in these publications. The VOS Viewer was used to analyze keyword co-occurrence and it obtained graphs that explore the most common themes illustrating the research trends and hotspots in the field of economic growth, economic development, and poverty (Van Eck, N. J. \& Waltman, L., 2011). The co-occurrence threshold of the keywords was set, as 50 and 57 items were incorporated into visualization (see Figure 4).

In Figure $4 \mathrm{a}$, the position of a keyword in the two-dimensional space is determined by applying WOS mapping techniques in 2D (Van Eck, Waltman, Dekker, \& van den Berg, 2010) space for each term, and the size of the circles represents keyword occurrences. The larger the circle, the more often a keyword has been co-selected. Keywords such as 'economic development, 'poverty', 'economic growth and 'poverty alleviation had the highest strength. Line thickness is a measure of the strength of the association between keywords relative to each other. The distance between two keywords implies the relative strength of their relationship and the similarity of the topic. The distance between two keywords shows the relative strength of their relatedness and topic similarity. The same color circles suggest a cluster of many interlinked keywords and underline an individual aspect or subtopic within the same high-level science field. The cooccurrences network of keywords in Figure 4a clearly illustrates four distinct clusters.

Figure 4. Co-occurrences network of keywords, generated with the VOS Viewer (a - network visualization based on co-occurrences keywords; b - network visualization based on the co-occurrences keywords and average publication per year scores)

a)

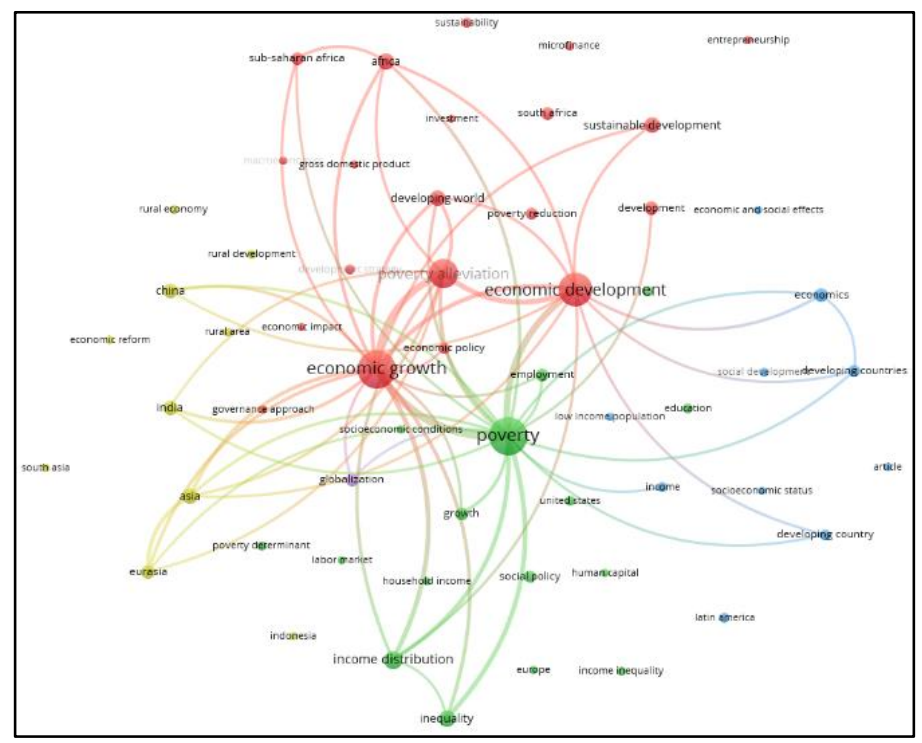




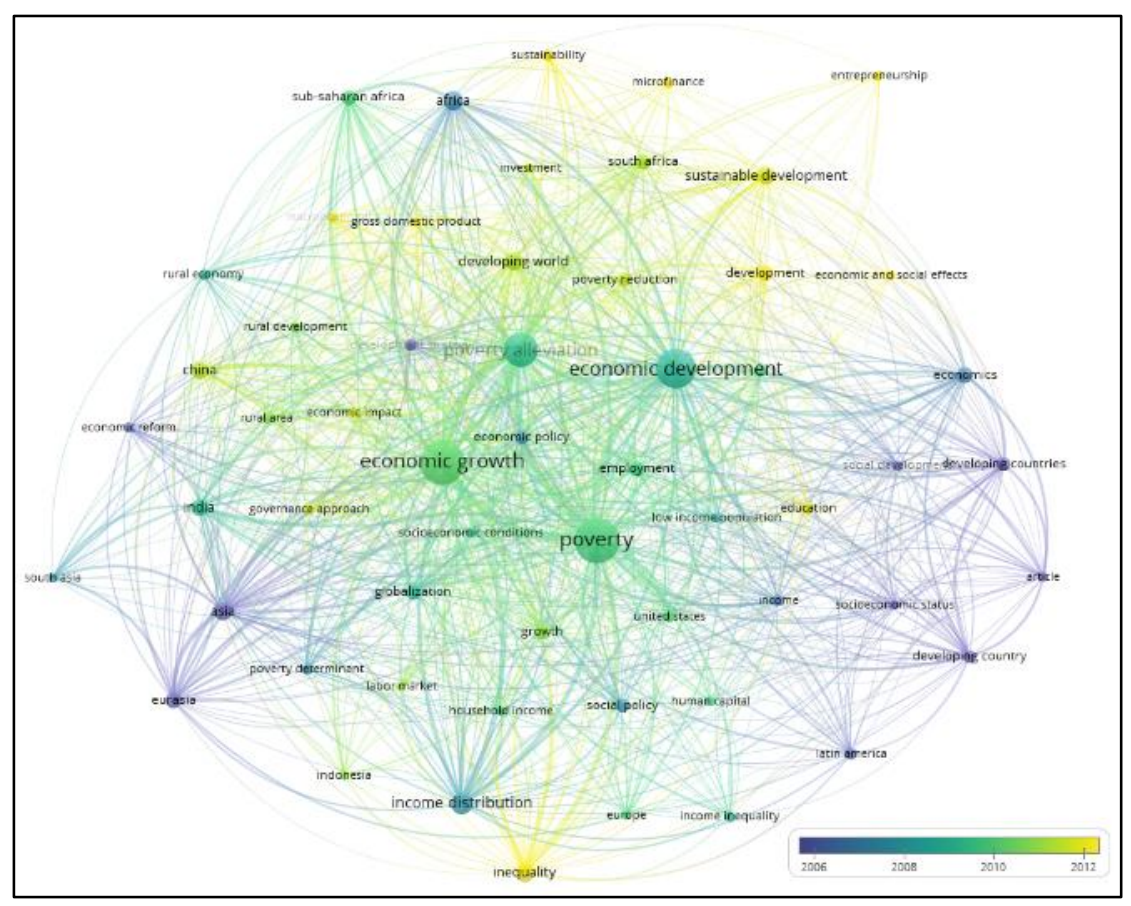

b)

By analyzing the key node circles, appropriate labels of the four main clusters could be assigned to each of them. Specifically, as was shown in the red cluster (Figure 4a, cluster 1, 20 items), keywords such as economic growth, economic development, poverty alleviation, Africa, developing world, sustainable development, development, poverty reduction, and such, apparently were relevant to the topic of "economic development". In the green cluster (Figure 4a, cluster 2, 16 items), keywords such as poverty, income distribution, inequality, growth, employment, social policy, and such, focused on poverty and income distribution. Next, in the blue cluster (Figure 4a, cluster 3, 10 items), keywords such as economics, developing countries, income, social development, low-income population, economic and social effects, socioeconomic status, and such, concentrated on the aspect of "Socioeconomic status". In the yellow cluster (Figure 4a, cluster 4, 10 items), keywords such as Asia, India, China, Eurasia, rural economy, rural area, rural development, and such, were associated with "region development" topics.

As is shown in Figure 4b, different colors were used to represent the time-varying keyword co-occurrences from 2006 (in dark purple) to 2012 (in yellow). It may be seen that for a keyword or term belonging to "region development" of Cluster 4, the average year of publication is the year 2006. For keyword in Cluster 1 "economic development," the average publication year has shifted to the period from 2008 to 2010 . In the yellow period (around 2012), keywords that belong to cluster 3 of "Socioeconomic status" appear, which is still a hot topic on the economic scene is today.

\section{Conclusions and research opportunities}

This analysis evaluated the global research trends in economic development and poverty publications from 1970 to 2019. In the last 20 years, the issue of economic development and poverty has been a field with extensive studies, most significantly since the year 2000. There is an increasing interest among researchers related to economic growth and development and poverty, which is consistent with the fact that economic growth and development, are one of the best directions on the path to poverty reduction.

This analysis used the SCOPUS databases to retrieve publications from 1970 to 2019. The survey was conducted during the first week of February 2020, and a total of 5,337 publications were returned from the main search. Regarding the number of publications per year, a growing pattern of Poverty and Economic growth and development occurs in the last forty years. With 21 publications, Martin Ravallion is the author, while "A new data set measuring income inequality" (1996), by K. Deininger and L., is the most cited article. Data show the greatest number of publications (99) in the World Development Journal. World 
Development Journal and Journal of International Development have the largest node sizes. By evaluating the countries that were most influential based on the number of publications published in the collection by each country, we concluded that, with 1.262 publications, the USA was the first. The most frequently used keyword is 'poverty' with the highest frequency of occurrence, followed by 'economic growth', 'economic development, 'poverty alleviation, etc. Broader research should include more keywords in analysis in first "disease", "health", "infection", etc.

As far as constraints of this bibliometric study, the main collection was limited to the SCOPUS database. Different international databases (e.g., WoS or PubMed) should be combined in future research. However, the Scopus database was picked as a data source, because it is the largest citation and abstract database of peer-reviewed scientific literature, and the most widely used for search and analysis of scientific publications. Secondly, the bibliometric method of research could be performed only for the current classifications used in SCOPUS. Based on these constraints, a more in-depth review of the content is recommended for further research in the characterization of the bibliometric analysis.

\section{References}

Adams, R. H. (2003). Economic growth, inequality, and poverty: Findings from a new data set (Vol. 2972): World Bank Publications.

Aghaei Chadegani, A., Salehi, H., Yunus, M., Farhadi, H., Fooladi, M., Farhadi, M., \& Ale Ebrahim, N. (2013). A comparison between two main academic literature collections: Web of Science and Scopus databases. Asian Social Science, 9(5), 18-26. DOI: doi:10.5539/ass.v9n5p18

Beck, T., Demirgüç-Kunt, A., \& Levine, R. (2007). Finance, inequality, and the poor. Journal of Economic Growth, 12(1), 27-49. doi: https://doi.org/10.1007/s10887-007-9010-6

Beckerman, W. (1992). Economic growth and the environment: Whose growth? whose environment? World Development, 20(4), 481-496. doi: 10.1016/0305-750X(92)90038-W

Cardoso, S. M., \& Teixeira, A. A. C. (2020). The Focus on Poverty in the Most Influential Journals in Economics: A Bibliometric Analysis of the "Blue Ribbon" Journals. Poverty \& Public Policy, 12(1), 10-42. doi: https://doi.org/10.1002/pop4.269

Council of Europe. (2020). Poverty. Retrieved 26.08.2020, Retrieved from https://www.coe.int/en/web/compass/poverty\#5

Deininger, K., \& Squire, L. (1996). A new data set measuring income inequality. World Bank Economic Review, 10(3), 565-591. doi: 10.1093/wber/10.3.565

DFID, G. B. (2008). Growth: building jobs and prosperity in developing countries. London: Department for International Development.

Diener, E., \& Biswas-Diener, R. (2002). Will money increase subjective well-being? A literature review and guide to needed research. Social Indicators Research, 57(2), 119-169. doi: 10.1023/A:1014411319119

Dollar, D., \& Kraay, A. (2002). Growth is good for the poor. Journal of Economic Growth, 7(3), 195-225. doi: 10.1023/A:1020139631000

Dollar, D., \& Kraay, A. (2004). Trade, growth, and poverty. Economic Journal, 114(493), F22-F49. doi: 10.1111/j.0013-0133.2004.00186.x

Fields, G. S. (1989). Changes in poverty and inequality in developing countries. The World Bank Research Observer, 4(2), 167-185.

Glaeser, E. L., La Porta, R., Lopez-de-Silanes, F., \& Shleifer, A. (2004). Do institutions cause growth? Journal of Economic Growth, 9(3), 271-303. doi: 10.1023/B:JOEG.0000038933.16398.ed 
Islam, R. (2004). The nexus of economic growth, employment and poverty reduction: An empirical analysis. Recovery and Reconstruction Department International Labour Office. 92-2-115485-8[ISBN]

Kwon, H.-j., \& Yi, I. (2015). Economic development and poverty reduction in Korea: Governing multifunctional institutions. In Bangura Y. (Ed.), Developmental Pathways to Poverty Reduction (pp. 175-200). London: Palgrave Macmillan. doi: https://doi.org/10.1057/9781137482549_8

Lahat, L. (2017). The Effects of Knowledge about Poverty, Exposure to Poverty and Trust on Policymakers' Perceptions about Poverty, Social Policy and Administration, doi: $10.1111 /$ spol.1233210.1111/spol.12332

Lopez, J. H. (2006). The relative roles of growth and inequality for poverty reduction. Poverty reduction and growth: Virtuous and vicious circles. W ashington, DC: The World Bank.

Myers, J. (2020). India is now the world's 5th largest economy. Retrieved 20.3.2020, 2020, Retrieved from https://www.weforum.org/agenda/2020/02/india-gdp-economy-growth-uk-france/

QS Higher Education System Strength Rankings. (2020). Retrieved 26.08.2020. Retrieved from https://www.qs.com/top-higher-education-systems-in-the-world/

Ravallion, M. (2001). Growth, inequality and poverty: looking beyond averages. World Development, 29(11), 1803-1815.

Ravallion, M., \& Chen, S. (1999). What can new survey data tell us about recent changes in distribution and poverty? : The World Bank. doi: https://doi.org/10.1596/1813-9450-1694

Ravallion, M., \& Chen, S. (2011). Weakly relative poverty. Review of Economics and Statistics, 93(4), 1251-1261. doi: https://doi.org/10.1162/REST_a_00127

Ravallion, M. (2011). The Two Poverty Enlightenments Historical Insights from Digitalized Books Spanning Three Centuries, The World Bank, doi: https://doi.org/10.1596/1813-9450-5549

Rodrik, D. (2008). One economics, many recipes: Globalization, institutions, and economic growth: Princeton University Press. doi: DOI: $10.2307 /$ j.ctvem4jbh

Roemer, M., \& Gugerty, M. K. (1997). Does economic growth reduce poverty? : Harvard Institute for International Development Cambridge, MA.

Škare, M., \& Družeta, R. P. (2016). Poverty and economic growth: a review. Technological and Economic Development of Economy, 22(1), 156-175. doi: 10.3846/20294913.2015.1125965

Taylor, E. J. (1999). The new economics of labour migration and the role of remittances in the migration process. International Migration, 37(1), 63-88. doi: https://doi.org/10.1111/1468-2435.00066

Teixeira, A. A. C., \& Carvalho, L. (2014). Where are the poor in mainstream international economics? Poverty \& Public Policy, 6(3), 215-238. doi: https://doi.org/10.1002/pop4.77

Todaro, M. P., \& Smith, S. C. (2015). Economic Development (12th ed.): United Kingdom: Pearson Education, Inc.

Van den Berg, H. (2017) Economic growth and development (3th ed): Singapore: World Scientific Publishing Company, Co. Pte. Ltd.

Van Eck, N. J., \& Waltman, L. (2011). Text mining and visualization using VOSviewer. arXiv preprint arXiv:1109.2058. 
Van Eck, N. J., Waltman, L., Dekker, R., \& van den Berg, J. (2010). A comparison of two techniques for bibliometric mapping: Multidimensional scaling and VOS. Journal of the American Society for Information Science and Technology, 61(12), 2405-2416. doi: https://doi.org/10.1002/asi.21421

World Bank. (2020a). Poverty and Inequality. Retrieved 26.08.2020, Retrieved from https://datatopics.worldbank.org/world-development-indicators/themes/poverty-and-inequality.html

World Bank. (2020b). Poverty Overview. Retrieved 20.3.2020, 2020, Retrieved from https:/ /www.worldbank.org/en/topic/poverty/overview

World Bank. (2020c). Indicators. Retrieved 26.08.2020. Retrieved from https://data.worldbank.org/indicator

Appendix 1

\begin{tabular}{|c|c|c|c|c|c|c|}
\hline & \multicolumn{2}{|c|}{ Social Sciences } & \multicolumn{2}{|c|}{$\begin{array}{l}\text { Business, Management and } \\
\text { Accounting }\end{array}$} & \multicolumn{2}{|c|}{$\begin{array}{l}\text { Economics, Econometrics } \\
\text { and Finance } \\
\end{array}$} \\
\hline & $\begin{array}{l}\text { Total number } \\
\text { of publication }\end{array}$ & $\begin{array}{l}\text { Topic related } \\
\text { publication }\end{array}$ & $\begin{array}{l}\text { Total number } \\
\text { of publication }\end{array}$ & $\begin{array}{l}\text { Topic related } \\
\text { publication }\end{array}$ & $\begin{array}{l}\text { Total number } \\
\text { of publication }\end{array}$ & $\begin{array}{l}\text { Topic related } \\
\text { publication }\end{array}$ \\
\hline 1970 & 15.109 & 1 & 2359 & 0 & 1869 & 1 \\
\hline 1971 & 16.149 & 0 & 2462 & 0 & 2176 & 1 \\
\hline 1972 & 17.387 & 0 & 2747 & 0 & 2189 & 0 \\
\hline 1973 & 19.007 & 1 & 3475 & 0 & 2425 & 0 \\
\hline 1974 & 20.704 & 4 & 4053 & 0 & 2990 & 0 \\
\hline 1975 & 21.653 & 3 & 4181 & 0 & 2902 & 2 \\
\hline 1976 & 22.852 & 1 & 4322 & 0 & 3096 & 3 \\
\hline 1977 & 24.479 & 0 & 4751 & 0 & 3528 & 1 \\
\hline 1978 & 26.326 & 5 & 4901 & 1 & 3973 & 2 \\
\hline 1979 & 28.775 & 0 & 5170 & 1 & 4676 & 2 \\
\hline 1980 & 30.215 & 4 & 5409 & 2 & 4329 & 3 \\
\hline 1981 & 32.021 & 4 & 5827 & 0 & 4594 & 2 \\
\hline 1982 & 34.614 & 6 & 6550 & 1 & 4910 & 3 \\
\hline 1983 & 36.090 & 2 & 7346 & 0 & 5166 & 1 \\
\hline 1984 & 37.991 & 10 & 7804 & 2 & 5526 & 4 \\
\hline 1985 & 38.033 & 8 & 7992 & 0 & 6273 & 9 \\
\hline 1986 & 39.479 & 6 & 8293 & 0 & 6165 & 3 \\
\hline 1987 & 41.473 & 7 & 8556 & 0 & 6320 & 2 \\
\hline 1988 & 43.492 & 7 & 9511 & 1 & 6599 & 3 \\
\hline 1989 & 45.241 & 15 & 10296 & 2 & 7120 & 5 \\
\hline 1990 & 47.687 & 18 & 12555 & 2 & 7605 & 7 \\
\hline 1991 & 49.002 & 17 & 12441 & 4 & 7879 & 7 \\
\hline 1992 & 50.473 & 36 & 13402 & 1 & 8217 & 10 \\
\hline 1993 & 53.583 & 26 & 14392 & 0 & 8704 & 9 \\
\hline 1994 & 55.605 & 16 & 15797 & 1 & 9527 & 7 \\
\hline 1995 & 58.451 & 33 & 17139 & 2 & 10191 & 11 \\
\hline
\end{tabular}




\begin{tabular}{|c|c|c|c|c|c|c|}
1996 & 66.062 & 33 & 24345 & 3 & 12322 & 15 \\
\hline 1997 & 67.021 & 32 & 23613 & 2 & 12253 & 9 \\
\hline 1998 & 70.735 & 43 & 25335 & 1 & 12800 & 16 \\
\hline 1999 & 70.928 & 47 & 25417 & 5 & 13680 & 16 \\
\hline 2000 & 77.774 & 76 & 29376 & 3 & 15289 & 26 \\
\hline 2001 & 80.988 & 64 & 41890 & 1 & 15097 & 26 \\
\hline 2002 & 93.231 & 78 & 44986 & 11 & 16809 & 29 \\
\hline 2004 & 106.868 & 69 & 49432 & 13 & 25644 & 37 \\
\hline 2005 & 111.919 & 90 & 49356 & 17 & 26120 & 55 \\
\hline 2006 & 129.065 & 92 & 63558 & 21 & 31445 & 51 \\
\hline 2007 & 145.746 & 114 & 63557 & 27 & 33155 & 48 \\
\hline 2008 & 184.511 & 136 & 66478 & 33 & 40162 & 59 \\
\hline 2009 & 203.227 & 133 & 66256 & 38 & 43688 & 90 \\
\hline 2010 & 218.170 & 149 & 72548 & 47 & 48128 & 110 \\
\hline 2011 & 240.607 & 176 & 73961 & 40 & 49471 & 82 \\
\hline 2012 & 258.481 & 169 & 71518 & 48 & 54149 & 97 \\
\hline 2013 & 277.656 & 166 & 80388 & 63 & 63616 & 121 \\
\hline 2014 & 276.118 & 212 & 80784 & 74 & 61284 & 118 \\
\hline 2015 & 287.708 & 176 & 81655 & 79 & 64089 & 125 \\
\hline 2016 & 300.127 & 181 & 91990 & 80 & 67930 & 115 \\
\hline 2017 & 321.212 & 209 & 98061 & 92 & 71780 & 143 \\
\hline 2018 & 326.270 & 204 & 95726 & 91 & 66435 & 127 \\
\hline 2019 & 338.553 & 212 & 106419 & 80 & 60999 & 104 \\
\hline$A 5 p$ & 123 & 66014 & 30 & 3653 & \\
\hline
\end{tabular}

Appendix 1 (Cont'd) Data collected from the Scopus database on October $1^{\text {st }} 2020$. 